\title{
Effect of Ether Mono Amine Collector on the Cationic Flotation of Micaceous Minerals-A Comparative Study
}

\author{
Arash Tohry ${ }^{1}$, Reza Dehghan ${ }^{1, *}$, Hossein Mohammadi-Manesh $\left.{ }^{2}{ }^{(}\right)$, Laurindo de Salles Leal Filho ${ }^{3}(\mathbb{D}$ \\ and Saeed Chehreh Chelgani $4, * \mathbb{1}$
}

1 Mineral Processing, Department of Mining and Metallurgical Engineering, Yazd University, Yazd 89195-741, Iran; Arashtohry@stu.yazd.ac.ir

2 Department of Chemistry, Faculty of Science, Yazd University, Yazd 89195-741, Iran;

Mohammadimanesh@yazd.ac.ir

3 Laboratory of Transport Phenomena and Chemistry of Interfaces, Department of Mining and Petroleum Engineering, University of São Paulo, São Paulo 05508-010, Brazil; lauleal@usp.br

4 Minerals and Metallurgical Engineering, Department of Civil, Environmental and Natural Resources Engineering, Luleå University of Technology, SE-971 87 Luleå, Sweden

* Correspondence: rdehghans@yazd.ac.ir (R.D.); Saeed.chelgani@ltu.se (S.C.C.)

Citation: Tohry, A.; Dehghan, R.; Mohammadi-Manesh, H.; Filho, L.d.S.L.; Chelgani, S.C. Effect of Ether Mono Amine Collector on the Cationic Flotation of Micaceous Minerals-A Comparative Study. Sustainability 2021, 13, 11066. https:/ / doi.org/10.3390/su131911066

Academic Editor: Glen Corder

Received: 29 August 2021

Accepted: 4 October 2021

Published: 7 October 2021

Publisher's Note: MDPI stays neutral with regard to jurisdictional claims in published maps and institutional affiliations.

Copyright: (C) 2021 by the authors. Licensee MDPI, Basel, Switzerland. This article is an open access article distributed under the terms and conditions of the Creative Commons Attribution (CC BY) license (https:// creativecommons.org/licenses/by/ $4.0 /)$.

\begin{abstract}
Micaceous minerals, known as layer silicates, are counted mostly as the gangue minerals associated with valuable minerals, especially iron oxides. They mainly reject through the reverse flotation process using the cationic collectors, e.g., ether amines, to improve process sustainability. Although ether amines have been applied for floating the wide range of silicates, few investigations explored their adsorption behaviors on the micaceous minerals. In this study, flotation of phlogopite, biotite, and quartz (for comparison purposes) in the presence of Flotigam ${ }^{\circledR}$ EDA (EDA) (commercial ether monoamine collector), at $\mathrm{pH} 10$ was investigated through the single mineral micro-flotation experiments. Adsorption behaviors were explored by the contact angle, residual surface tension measurements, and zeta potential analyses. Micro-flotation outcomes indicated that the quartz floatability was more than phlogopite and biotite. In the presence of $30 \mathrm{mg} / \mathrm{dm}^{3} \mathrm{EDA}$, their recoveries were 97.1, 46.3, and 63.8\%, respectively. Increasing EDA concentration made a substantial increase in micaceous minerals' floatability. Adsorption assessments confirmed that increasing the EDA concentration resulted in higher adsorption of EDA onto the surface of micaceous minerals than the quartz (all by physical adsorption). Such a behavior could be related to the nature of micaceous minerals, including their layer structure and low hardness.
\end{abstract}

Keywords: Flotigam ${ }^{\circledR}$ EDA; micaceous minerals; quartz; adsorption

\section{Introduction}

Mineral flotation separation, as a physicochemical process, is a well-known technique for the purification of target minerals which become finely liberated (mainly +25-100 micron) [1,2] Currently, froth flotation is globally considered for processing various finely disseminated minerals (sulphides [3-6], oxides [7-12], silicates [7,8,10,12], phosphates [7,13,14], etc). In direct flotation, target minerals are floated, whereas in reverse flotation, valuable minerals are sunk, and gangue minerals are rejected in the froth phase [1,2]. Silicate can be separated by flotation beneficiation. Although some silicates can be considered as commercial minerals, they are mostly known as gangue associated with other valuable oxides [8,9,12,15-18], semi-soluble minerals $[13,14]$, and sulfides [5,6]. In terms of processing, silicates could be classified as simple and complex, in which quartz and micaceous minerals should be named as simple and complex silicates, respectively [12]. Micaceous minerals, unlike quartz, include metallic ions, e.g., $\mathrm{Mg}^{2+}, \mathrm{Fe}^{3+}$, and $\mathrm{Al}^{3+}$, which turn them into complicated phases for the separation by flotation, especially for iron ore processing $[12,16,19,20]$. Therefore, enhancing their rejection would improve the metallurgical responses, reduce downstream penalties, and provide sustainable production. 
Since the surface of silicates is covered generally by silanol groups ( $\mathrm{Si-O}-$ ), and in some cases with the combination of $\mathrm{M}-\mathrm{O}-$ and $\mathrm{Si}-\mathrm{O}-$-, electrostatic adsorption of cationic collector would be essential for controlling the silicate flotation process [19,21]. It was found that the electrokinetic properties of the diaspore and three aluminosilicate minerals, including kaolinite, pyrophyllite, and illite, are highly dependent on the number of broken $\mathrm{Al}-\mathrm{O}-$ and $\mathrm{Si}-\mathrm{O}-$ bonds per unit cell [22]. The ratio of broken $\mathrm{Al}-\mathrm{O}-$ to $\mathrm{Si}-\mathrm{O}-$ bonds on various edge surfaces appears to play a dominant role in determining the surface properties of various aluminosilicates and their flotation responses to collector solutions: a lower aluminum to silicon ratio of pyrophyllite and illite responds more favorably to cationic collector adsorption [22]. It is well known that due to the negative surface charge of almost all micaceous minerals within $\mathrm{pH}$ range from 2 to 12 , the surface of these minerals would not potentially react to anionic collectors without using an activator [13,19]. However, some studies depicted complex silicates with more alkaline surfaces (higher zero points of charge), which can somewhat float with anionic collectors such as fatty acids and alkyl sulfates, without activators into the conditioning step $[13,19]$. In this case, the chemical interaction of the collector with metal sites on certain silicates provides the means for affecting the flotation selectivity $[13,19]$. On the other hand, micaceous minerals can be floated efficiently by amines. However, it was reported that the expected floatability of these minerals could not be promising in the presence of cationic collectors, especially at concentrations where other silicates such as quartz can be floated [23-27].

In alkaline conditions, the reverse cationic flotation is recognized as the most efficient separation process for floating silicates and removing them from valuable minerals such as titan and iron oxides $[12,16,20,21,24-29]$. In this process, collectors play an essential role in achieving the maximum flotation selectivity. Various amines such as primary aliphatic amines [29], diamines [30], and quaternary amines [31] have been utilized as collectors for floating silicates $[30,32]$. Ether amines are more efficient among these cationic collectors due to their higher solubility in pulp, collectivity, and frothing ability $[18,30,32,33]$. These features would be due to the $\mathrm{N}$-alkyloxy propylamine $\left(\mathrm{R}-\mathrm{O}-\left(\mathrm{CH}_{2}\right)_{3}-\mathrm{NH}_{2}\right)$ formation $[17,32]$. Thus, ether amines could play both collector and frother roles. An ion-molecular complex of ether amines in alkaline $\mathrm{pH}$ can form by associating an ammonium ion and dimerizing ammonium ions. The generated complexes are significantly surface-active that promote silicate flotation separation [20,32]. Given these advantages, ether amine collectors are used globally for silicate rejection in the iron ore processing plants (processing of more than 80 million tons of iron ore concentrate in Brazil [34]).

Ether amines could also obtain more selectivity on silicates than the other typical cationic collectors $[17,30]$. Filippov et al. (2010) explored the amphibole floatability in the presence of ether amine and showed its efficiency was significantly higher than fatty acid amine [17]. Papini et al. (2001) conducted batch flotation tests on itabirite ore by using various cationic collectors [30]. They revealed that the provided separation efficiency of ether monoamines was quite higher than ether diamines and fatty amines [30]. For micaceous minerals, Leal Filho et al. (2002) demonstrated that more than $85 \%$ of phlogopite particles could be floated in the presence of a high ether amine dosage $\left(100 \mathrm{mg} / \mathrm{dm}^{3}\right.$; $\mathrm{pH}$ 10) [13]. Using a high concentration of ether diamine collector at $\mathrm{pH} 8$ showed that biotite and muscovite could make satisfactory floatability [24]. They also cause lower floatability of iron minerals comparing to fatty amines and diamines [30].

The application of Flotigam ${ }^{\circledR}$ EDA (commercial ether monoamine) and its mechanism in the floatability of quartz have been reported in several studies [35-37]. Although few studies explored the effect of ether amines on the micaceous minerals' floatability (by conducting micro-flotation tests) [13,24], its effect and adsorption behavior on their surfaces, especially on their biotite and phlogopite surfaces, were not addressed in detail. Therefore, this study is going to fill this gap and explore the ether monoamine adsorption behaviors onto the biotite and phlogopite surfaces in alkaline conditions and compare it with quartz to enhance the flotation separation sustainability. For this purpose, microflotation tests were performed on pure phlogopite, biotite, and quartz at $\mathrm{pH} 10$ to evaluate 
the effect of the collector on their floatability. The contact angle, residual surface tension, and zeta potential measurements were used to understand the surface interactions in the presence of Flotigam ${ }^{\circledR}$ EDA.

\section{Materials and Methods}

\subsection{Materials}

Pure quartz was sampled from "Mineração Jundu from Descalvado-SP", Brazil. The pure biotite $\left(\mathrm{K}(\mathrm{Mg}, \mathrm{Fe})_{3} \mathrm{AlSi}_{3} \mathrm{O}_{10}(\mathrm{~F}, \mathrm{OH})_{2}\right)$ sample was obtained from the Socorro-Guaxupé Nappe area, Minas Gerais, Brazil. The pure phlogopite $\left(\mathrm{KMg}_{3} \mathrm{AlSi}_{3} \mathrm{O}_{10}(\mathrm{~F}, \mathrm{OH})_{2}\right)$ sample was sampled from Azartalgh Mica mine, West Azerbaijan, Iran. The captive bubble method (CBM) was used for assessing the contact angle. Large pieces of the fresh minerals were chosen to reduce the possible effect of cracks, and then they were cut and followed by polishing and preparing. A hand hammer was used for crushing samples in a porcelain mortar. Samples were then wet sieved to achieve size fractions of $-75+25 \mu \mathrm{m}$, aiming to use for the micro-flotation, residual surface tension experiments, and $-25 \mu \mathrm{m}$, for the zeta potential tests. The chemical composition of samples was determined by $\mathrm{X}$-ray fluorescence (Table 1). Belsorp mini-II equipment (Bel Japan Inc.) was used to do the BET (Brunauer-Emmett-Teller) assessment and measure the specific surface area of pure minerals. Nitrogen gas at $77 \mathrm{~K}$ was utilized for all measurements. The results of BET measurements are presented in Table 1.

Table 1. Chemical composition of mineral samples and their representative BET.

\begin{tabular}{|c|c|c|c|c|c|c|c|c|c|}
\hline \multirow{2}{*}{ Pure Mineral } & \multicolumn{8}{|c|}{ Chemical Composition (\%) } & \multirow{2}{*}{$\begin{array}{l}\text { BET Specific } \\
\text { Surface }\left(\mathrm{m}^{2} / \mathrm{g}\right)\end{array}$} \\
\hline & $\mathrm{Fe}_{2} \mathrm{O}_{3}$ & $\mathrm{~K}_{2} \mathrm{O}$ & $\mathrm{Al}_{2} \mathrm{O}_{3}$ & $\mathrm{SiO}_{2}$ & $\mathrm{MgO}$ & $\mathrm{CaO}$ & $\mathrm{TiO}_{2}$ & $\mathrm{Na}_{2} \mathrm{O}$ & \\
\hline Quartz & 0.9 & - & 0.05 & 98.8 & 0.05 & 0.05 & - & 0.1 & 0.67 \\
\hline Phlogo-pite & 6.3 & 13.3 & 15.1 & 39.2 & 22.7 & 1.7 & 0.9 & 0.3 & 1.84 \\
\hline Biotite & 11 & 11 & 11.8 & 38.2 & 19.3 & 1.5 & 2.9 & 0.3 & 2.10 \\
\hline
\end{tabular}

Flotigam ${ }^{\circledR}$ EDA was provided from Clariant, Sao Paulo, Brazil. $\mathrm{HCl}$ and $\mathrm{NaOH}(1 \%$ $w / v$ analytical grade) were used to adjust the $\mathrm{pH}$. Analytical grades of acetone and ethanol were used to clean the flat plates. All reagents were prepared from Casa Americana (Brazil), and all tests were performed with distilled water.

\subsection{Micro-Flotation}

Micro-flotation experiments were conducted with various EDA concentrations (2.5, $7.5,15,30,75$, and $140 \mathrm{mg} / \mathrm{dm}^{3}$ ) at $\mathrm{pH} 10$. Each test was triplicated. Experiments were conducted in a $60 \mathrm{~mL}$ Hallimond tube using $50 \mathrm{~mL} / \mathrm{min}$ nitrogen flow rate, and the average results were considered. A mechanical stirrer was used at a speed of $1380 \mathrm{r} / \mathrm{min}$ [10]. During each test, $1.0 \mathrm{~g}$ of pure mineral sample and pre-adjusted water $(\mathrm{pH} \sim 10)$ were mixed into the tube, and then the slurry was treated for $1 \mathrm{~min}$. EDA was added into the cell in the next step, and conditioning was continued for 1 more minute. After conditioning, flotation was performed for $1 \mathrm{~min}$. Finally, hand scraping was used to collect the flotation products. Flotation products were filtered and dried at $40^{\circ} \mathrm{C}$. Their weights were separately measured and their metallurgical responses were calculated.

\subsection{Contact Angle Measurements}

Contact angle measurements were carried out by the Captive Bubble Method (CBM). Goniometer DSA25 (supplied by Kruss, Germany) was adopted to perform the contact angle assessments. Through the contact angle assessment, a glass syringe $(0.487 \mathrm{~mm}$ needle diameter) was employed to place an air bubble on the surface of the conditioned mineral plate. Each test was repeated at least 4 times. The Kruss program was used for accurate measurement. Ellipse fitting and Young-Laplace were considered for evaluating the bubble boundary and contour line [38]. The freshly mineral sample plates were first placed in a 
$100 \mathrm{~mL}$ beaker and conditioned with the desired EDA concentration by using a Rushton turbine at $\mathrm{pH} 10$ for $1 \mathrm{~min}$. After conditioning, samples were dried at ambient temperature, and then their contact angle was measured. According to the established procedure, samples were washed with acetone and water [38] before conducting the measurements.

\subsection{Residual Surface Tension Measurements}

Residual surface tension measurements for mineral suspensions (depletion method) were performed to evaluate the EDA adsorption onto the mineral surfaces; $2.0 \mathrm{~g}$ mineral samples $(-75+25 \mu \mathrm{m})$ were conditioned in a $100 \mathrm{~mL}$ beaker containing an aqueous solution with a certain EDA concentration of 15, 30, 75, and $140 \mathrm{mg} / \mathrm{dm}^{3}$ for $3 \mathrm{~min}$ at $\mathrm{pH} 10$. Then, mineral suspensions were filtered, and their residual solution was used to measure the surface tension by the Wilhelmy plate method by the automated force tensiometer K100 (Kruss, Germany). This method uses a platinum plate with a rectangular surface area and rough surface. The lower edge of the plate is placed in contact with the surface of the liquid, which advances over it, pulling it inside as a result of the "force of Wilhelmy" (Fw). The tensiometer counterbalanced and measured this force when it returned the plate to its initial position (liquid surface). The $\gamma \mathrm{LV}$ (surface tension; $\mathrm{mN} / \mathrm{m}$ ) value of the liquid is automatically determined by the instrument using Equation (1). To use such an equation, the value of $\theta$ (contact angle; degrees) must be zero. The roughness and careful cleaning of the plate guarantees this requirement [39].

$$
\gamma_{\mathrm{LV}}=\frac{\mathrm{F}_{\mathrm{w}}}{\mathrm{L} \cdot \operatorname{Cos} \theta}
$$

In Equation (1), $\mathrm{L}$ is the wetted length of the solid (perimeter at the liquid surface level). Programming of equipment was the base of measuring 50 measurements within a length of time of $400 \mathrm{~s}$. The surface tension of EDA solutions with the same concentrations was also measured. All measurements were repeated at least three times at $23.5 \pm 0.5^{\circ} \mathrm{C}$, and the average results were considered for the assessments. The final outcome was the average value of the last 15 measurements.

\subsection{Zeta Potential}

Before and after EDA treatment, zeta potential measurements of minerals were conducted using a Malvern zeta sizer (nano-ZS90). To determine the ZPC, zeta potentials were measured at different $\mathrm{pH}$ values (2-11), in the presence of $30 \mathrm{mg} / \mathrm{dm}^{3}$ EDA. Moreover, measurements were done at different concentrations of $\operatorname{EDA}\left(5,10,20,30,75\right.$, and $\left.140 \mathrm{mg} / \mathrm{dm}^{3}\right)$,

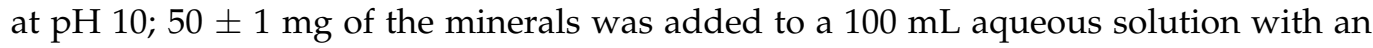
assigned EDA concentration for each $\mathrm{pH}$ value and stirred for $3 \mathrm{~min}$. Afterwards, the particles were settled for $5 \mathrm{~min}$. Consequently, around $3 \mathrm{~mL}$ of supernatant was collected with the syringe and transferred to Mavern special cell for the zeta potential measurement. All of the experiments were conducted at $22 \pm 1^{\circ} \mathrm{C}$ and repeated three times.

\section{Results}

\subsection{Micro-Flotation of Single Minerals}

Results (Figure 1) indicated that the quartz floatability increased with enhancing the collector dosage, and about $97 \%$ of quartz was floated at $30 \mathrm{mg} / \mathrm{dm}^{3}$ of EDA. Floatability of biotite was $63 \%$ when the EDA concentration reached $30 \mathrm{mg} / \mathrm{dm}^{3}$. However, phlogopite responded poorly to the cationic flotation, and its floatability at the same EDA concentration was only $46 \%$ (Figure 1 ). It was documented that amines with dosages higher than $1.0 \times 10^{-4} \mathrm{M}$ can maximize silicate floatability $[16,21,40]$. Thus, it is expected that satisfactory floatability for both biotite and phlogopite was obtained at such a concentration. However, it is observed that the recovery of micaceous minerals is relatively low, at $30 \mathrm{mg} / \mathrm{dm}^{3}$ concentrations of EDA (Figure 1). 


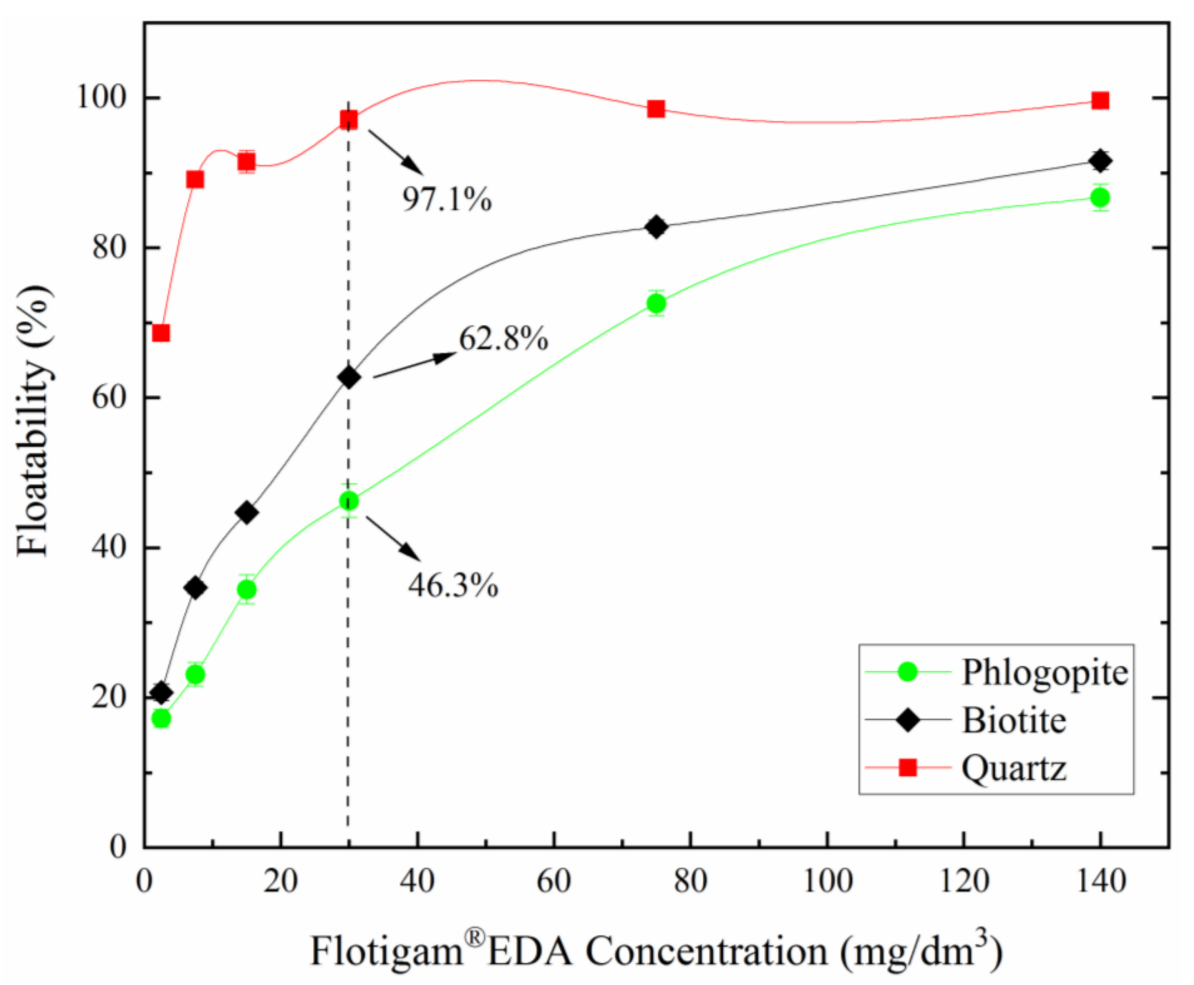

Figure 1. Floatability of phlogopite, biotite, and quartz as a function of Flotigam ${ }^{\circledR}$ EDA.

At concentrations above $30 \mathrm{mg} / \mathrm{dm}^{3}$, increasing the EDA concentration up to $140 \mathrm{mg} / \mathrm{dm}^{3}$ allowed the phlogopite and biotite recoveries to about 87 and 92\%, respectively. Such a trend was reported in cationic flotation of phlogopite with a dodecylamine collector [18]. Unlike micaceous minerals, the quartz recovery has almost remained constant at its maximum level (above 97\%). It shows that micaceous minerals need more collector species to cover the surface and, consequently, floating, than quartz. This outcome can be linked with BET-specific surface values of minerals (Table 1), where the surface area of layered silicates was significantly higher than the surface area of quartz, indicating that high collector concentrations are needed to cover micaceous surfaces. This phenomenon consequently renders their surface more hydrophobic; thus, much more collectors would be needed.

As shown in Figure 1, the quartz floatability was higher than phlogopite and biotite in the whole EDA concentrations. These outcomes are compatible with other investigations, proving the quartz recovery is higher than the micaceous minerals in cationic collectors [24,40]. This phenomenon could be due to the higher share of silanol groups on the surface of quartz than these micaceous minerals, which cause much higher cationic collectors' affinity towards $\mathrm{Si}$ sites than other metallic sites [21].

Rao et al. (1990) indicated that at alkaline conditions, using dodecylamine as a cationic collector was not successful for the flotation of mica minerals (biotite and muscovite with the mean particle size of $150 \mu \mathrm{m}$ ) [23]. However, Rao et al. (1995 and 1997) showed that at $\mathrm{pH} 7.5$ and presence of $10-5 \mathrm{M}$ primary amine, the floatability of muscovite and biotite (particle size $-75+5 \mu \mathrm{m}$ ) could be increased to 70 and $22.5 \%$, respectively [25,26]. Filippov et al. (2012) also reported that only $10 \%$ of muscovite and biotite are floated at $\mathrm{pH} 8$ with a low concentration of cationic collector (10-5 $\mathrm{M}$ of primary amine) [24]. These low floatabilities, compared to the results from Rao et al. (1995 and 1997) $[25,26]$, could be due to the different mineralogy of examined samples and also the differences between hydrodynamic flotation conditions [21]. Although the floatability of layer silicates with dodecylamine could be received to acceptable values, their flotation responses would be weaker than framework silicates, e.g., quartz [19]. Leal Filho et al. (2002) demonstrated that more than $85 \%$ of phlogopite particles could be floated in the presence of a high ether 
amine dosage (100 mg/ $\left.\mathrm{dm}^{3} ; \mathrm{pH} 10\right)$ [13]. However, at a lower $\mathrm{pH}(\mathrm{pH} 6.6)$, phlogopite recovery using $30 \mathrm{mg} / \mathrm{dm}^{3}$ dodecylamine was reported to be around $35 \%$ [27].

\subsection{Contact Angle Measurements}

The contact angle of untreated biotite was almost similar to quartz $\left(11.2^{\circ}\right.$ and $\left.11.1^{\circ}\right)$, while phlogopite showed the lowest value $\left(9.5^{\circ}\right)$ (Figure 2). These outcomes showed relatively higher phlogopite surface energy than the other two minerals. Since several oxygen sites are on the silicate surface, they could interact with water molecules based on their hydrogen bonds. Since the aqueous medium could substantially wet them, the contact angle of bare silicates should not be high. With increasing the EDA concentration, the contact angle of all minerals increased (increasing the EDA concentration increases these minerals' hydrophobicity). This incremental trend for all minerals was almost equal (Figure 2). This outcome was consistent with micro-flotation results (Figure 1), where the floatability of biotite was higher than phlogopite in the corresponding EDA concentration (30 mg/dm ${ }^{3} \mathrm{EDA}$ ). Generally, a higher contact angle value is expected to depict a higher flotation response for aim minerals compared to other minerals under the same conditions. However, the floatability of the treated quartz with $30 \mathrm{mg} / \mathrm{dm}^{3} \mathrm{EDA}$ was significantly more than phlogopite and biotite (Figure 1), while they had approximately a similar contact angle (Figure 2). This could be explained by the fact that the phlogopite and biotite floatability may be affected by physicochemical parameters of mineral flotation, e.g., surface dissolution, rheology, and particle shape characteristics.

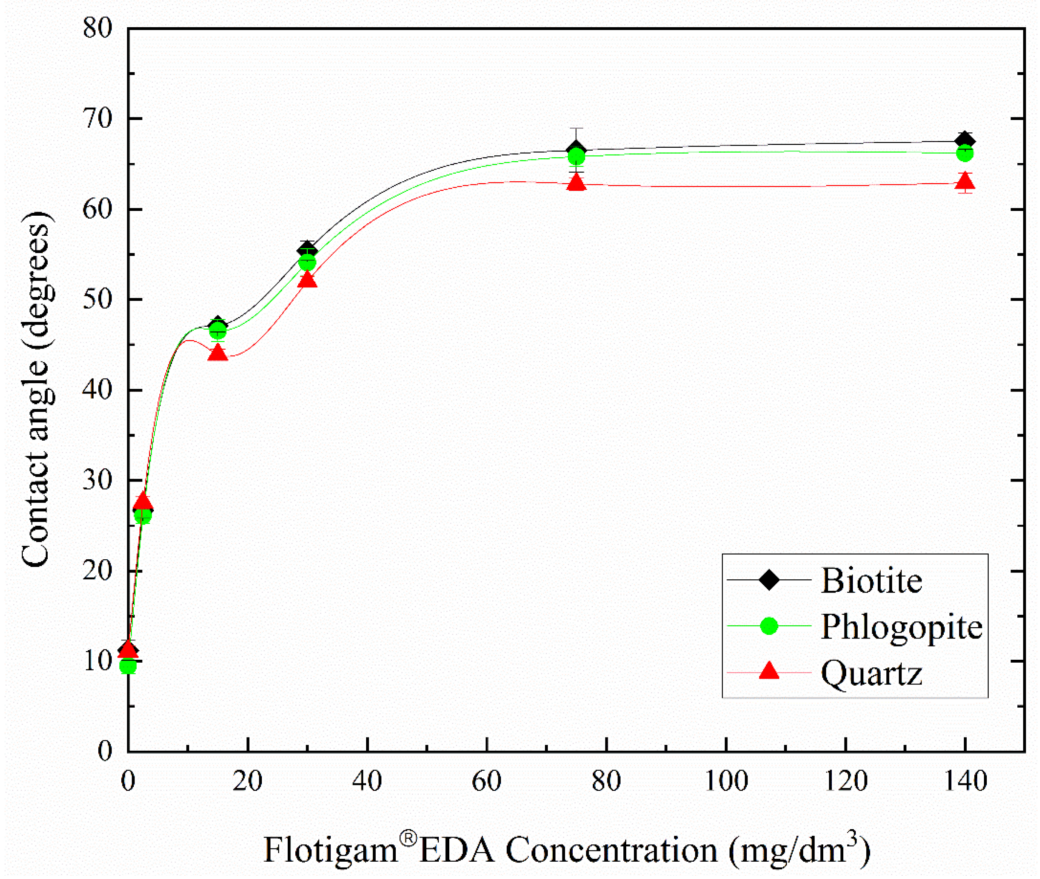

Figure 2. The contact angle of biotite, phlogopite, and quartz vs. Flotigam ${ }^{\circledR}$ EDA concentration (pH 10).

It should be noted that contact angle measurements were done for an ideal plate of minerals and may not be a precise representation of their fine particles or all their parts, especially for micaceous minerals. Micaceous mineral particles present anisotropic surfaces; therefore, two main sites should be considered for the flotation reagent adsorption: the side edges and the basal surface. The side edges are parallel to the (010) and (110) crystallographic orientations, and the basal surface is parallel to the crystallographic orientation of (001). The side edges commonly exhibited by the mica particles are frontal planes that present rims with broken bonds of the tetrahedral (mainly $\mathrm{Si}^{4+}$ and $\mathrm{Al}^{3+}$ ) and octahedral (mainly $\mathrm{Mg}^{2+}, \mathrm{Al}^{3+}, \mathrm{Fe}^{2+}, \mathrm{Fe}^{3+}$ ) cations [41]. Therefore, tetrahedral cations may offer more suitable sites for EDA adsorption [12,13,21]. 


\subsection{Residual Surface Tension}

The EDA adsorption on the mineral surfaces was investigated by measuring the residual surface tension of solutions. As results indicated (Figure 3), adding $30 \mathrm{mg} / \mathrm{dm}^{3}$ ( $\operatorname{Ln} \mathrm{C}=3.4)$ EDA decreased the surface tension of distilled water $\left(\gamma_{-} \mathrm{lv}=72.5 \mathrm{mN} / \mathrm{m}\right)$ to $32.8 \mathrm{mN} / \mathrm{m}$. This phenomenon demonstrates the EDA's strong ability, as a long-chain collector, for adsorbing onto air/water interface and mineral/water interface [1,42]. A similar pattern was reported by testing other cationic collectors, especially ether amine, which decreased the surface tension of the solution [43]. Outcomes indicated that the residual surface tension of quartz's suspension in various EDA concentrations $(15,30,75$, and $140 \mathrm{mg} / \mathrm{dm}^{3}$ ) was lower than phlogopite and biotite, which means a lower EDA adsorption on the quartz surface. The residual surface tension of biotite's suspension at $30 \mathrm{mg} / \mathrm{dm}^{3}$ EDA concentration $\left(\gamma \_l v=41.6 \mathrm{mN} / \mathrm{m}\right)$ was higher than phlogopite $\left(\gamma \_l \mathrm{v}=38.2 \mathrm{mN} / \mathrm{m}\right)$ and quartz $\left(\gamma_{-} \mathrm{lv}=37.8 \mathrm{mN} / \mathrm{m}\right)$. The higher surface area of biotite than the phlogopite and quartz can explain this phenomenon (Table 1).

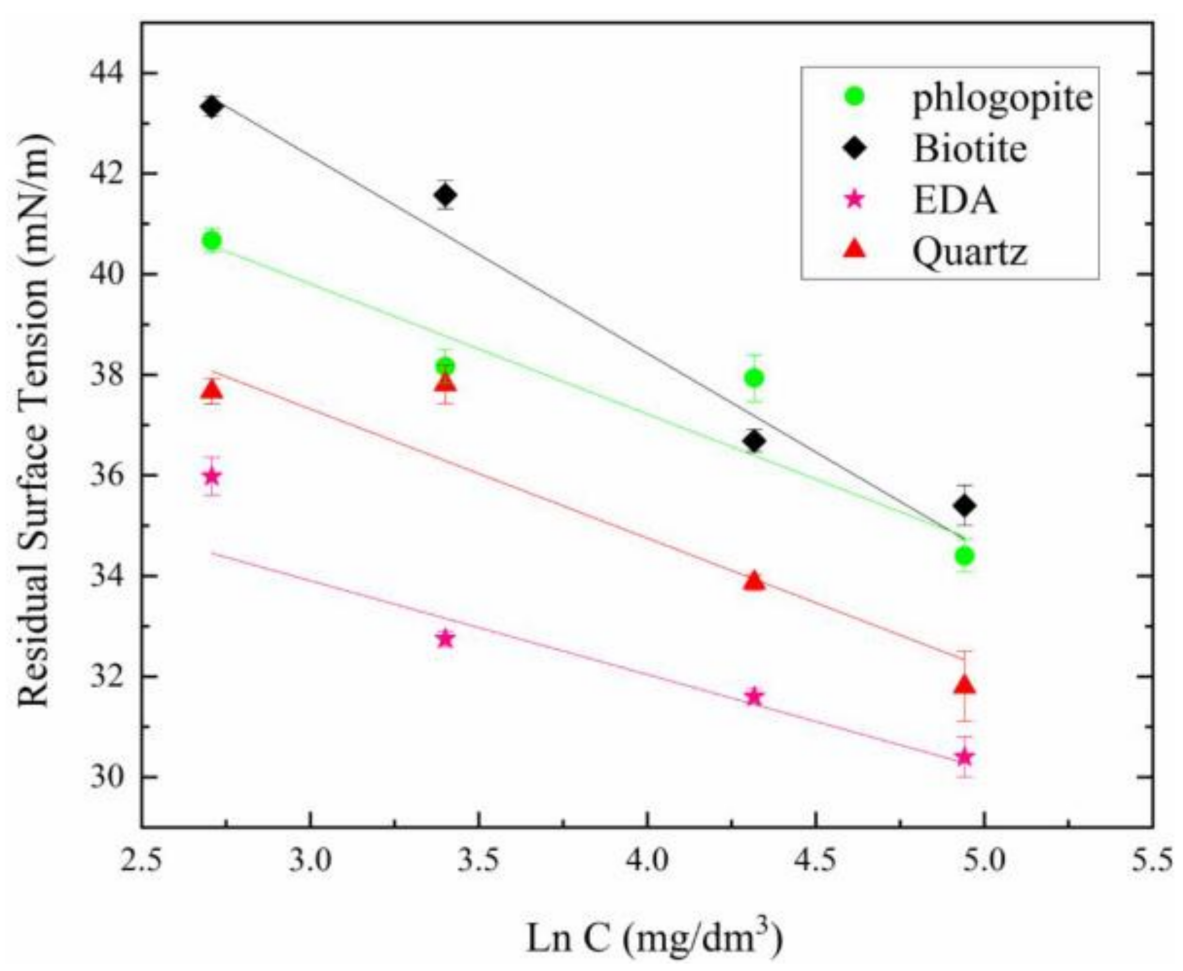

Figure 3. The residual surface tension of solutions containing biotite, phlogopite, and quartz after conditioning with different concentrations of Flotigam ${ }^{\circledR}$ EDA ( $\left.\mathrm{pH} 10\right)$.

As it was mentioned in the section on micro-flotation results, by increasing the EDA concentration, the tendency of micaceous minerals' surface to adsorption of EDA was increased. This phenomenon was also confirmed in residual surface tension measurements (Figure 3), in which a significant difference between the residual surface tension of micaceous minerals' suspension and quartz's suspension was observed. In fact, because of the low hardness of micaceous minerals, they tend to form very fine particles during milling, so-called "slimes". Therefore, this is not far from expectation to find micaceous minerals' particles with a higher surface area than the quartz, in an almost similar particle size fraction. On the other hand, regarding the layer structure of micaceous minerals, the layers which are weakly bonded together by interlayer cations such as $\mathrm{K}^{+}$and $\mathrm{Na}^{+}$, can easily peel off, and a new fresh surface creates when they are stirring in a suspension.

According to the above description, it is expected that after the external surfaces of fine micaceous particles are saturated with the collector, most outer mineral layers may be peeled off, the new fresh surface is frequently created, and demand for collector 
adsorbing is increased (Figure 4). The results of residual surface tension measurements (Figure 3) well confirm this claim. Moreover, with peeling off the layers and creating new ones, the hydrophobicity of mineral particles is lost. Consequently, their floatability is affected, which was observed in micro-flotation results (Figure 1), where, unlike quartz's particles, the floatability of micaceous minerals was low at EDA concentrations-lower than $75 \mathrm{mg} / \mathrm{dm}^{3}$.

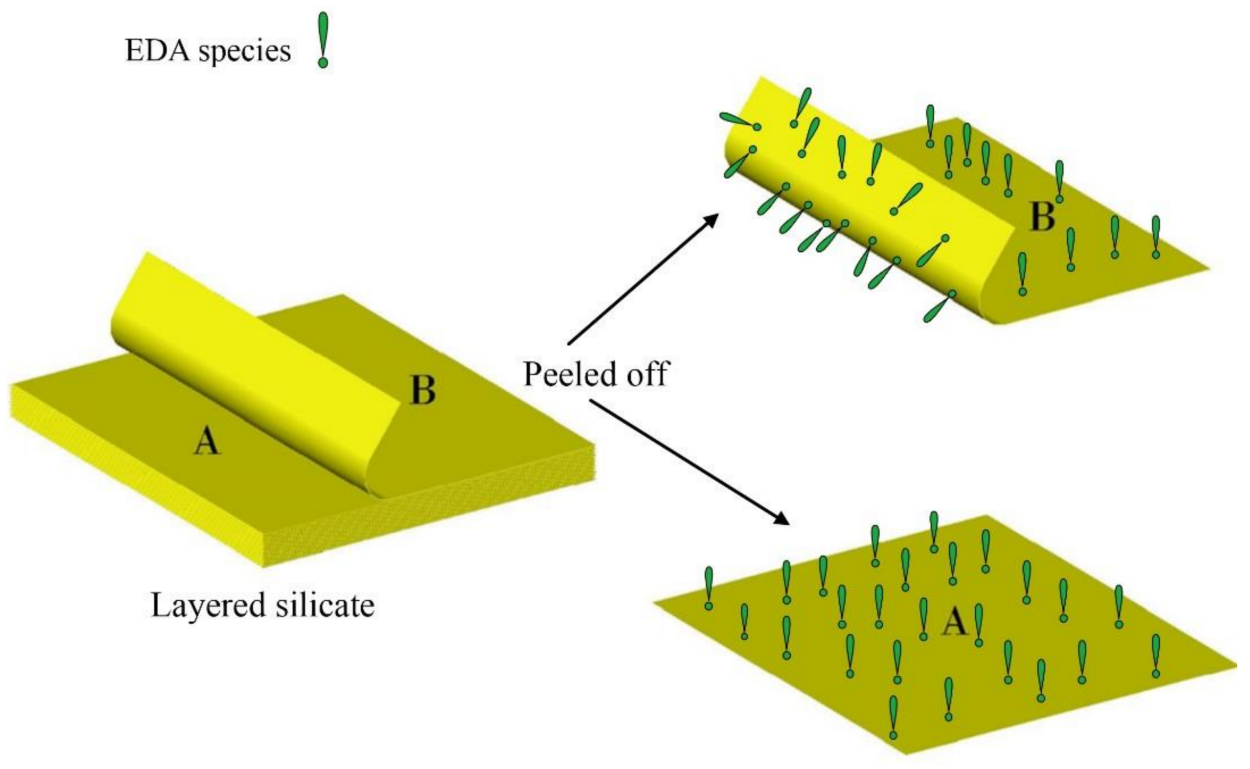

Figure 4. The schematic of peeling off and creating the new face of layered silicate and adsorption of collector onto these surfaces.

\subsection{Zeta Potential}

\subsection{1. $\mathrm{pH}$}

The zeta potential measurements were performed to provide more details about EDA interaction with the mineral surfaces. The zeta potential measurement results of pure minerals as a function of $\mathrm{pH}$ indicated (Figures 5-7) that the point of zero charges (pzc) of pure biotite, phlogopite, and quartz occurred around $\mathrm{pH}$ 2. Similar results were reported in other investigations (Table 2) $[10,13,24,37,44-50]$. EDA solution $\left(30 \mathrm{mg} / \mathrm{dm}^{3}\right)$ exhibited a positive charge over a wide $\mathrm{pH}$ range (Figures 5-7) which is associated with its cationic active species, e.g., aminium ion, $\mathrm{RNH} 3+$, and dimerization of aminium ions: (RNH3)2+. Severov et al. (2016) reported the same trend for amine acetate salts [21]. Adding EDA to pure minerals' suspensions, their IEP was shifted toward higher $\mathrm{pH}$ values, indicating that protonated amine molecules adsorbed on the mineral surfaces (Figures 5-7). The high shifting in the $\mathrm{pH}$ values was reported due to the interactions of cationic collectors, e.g., dodecyl and ether amine, and silicate surfaces [21].

The ZPC of biotite shifted to $\mathrm{pH}>4$ after conditioning with EDA (Figure 5). This could be due to the electrostatic attraction, which came from the interaction between EDA and the biotite surface. The same behavior was observed for phlogopite and quartz (Figures 6 and 7). For micaceous minerals, a weak increase in positive magnitudes of zeta potential was detected at $\mathrm{pHs}$ below ZPC, which indicated that surface charges repel each other, confirming physical interaction between their surfaces and EDA positive head molecules [51,52]. As could be seen, a higher ZPC shifting was achieved for phlogopite compared to biotite when EDA interacted with their surface. This result could be related to higher Mg sites on the phlogopite surface than the biotite (Table 1). Generally, MgO as a basic oxide has a high affinity for protons [53]; therefore, $\mathrm{Mg}$ sites on the phlogopite surface have a significant role in increasing zeta potentials and shifting the ZPC to higher $\mathrm{pH}$ values [21]. 


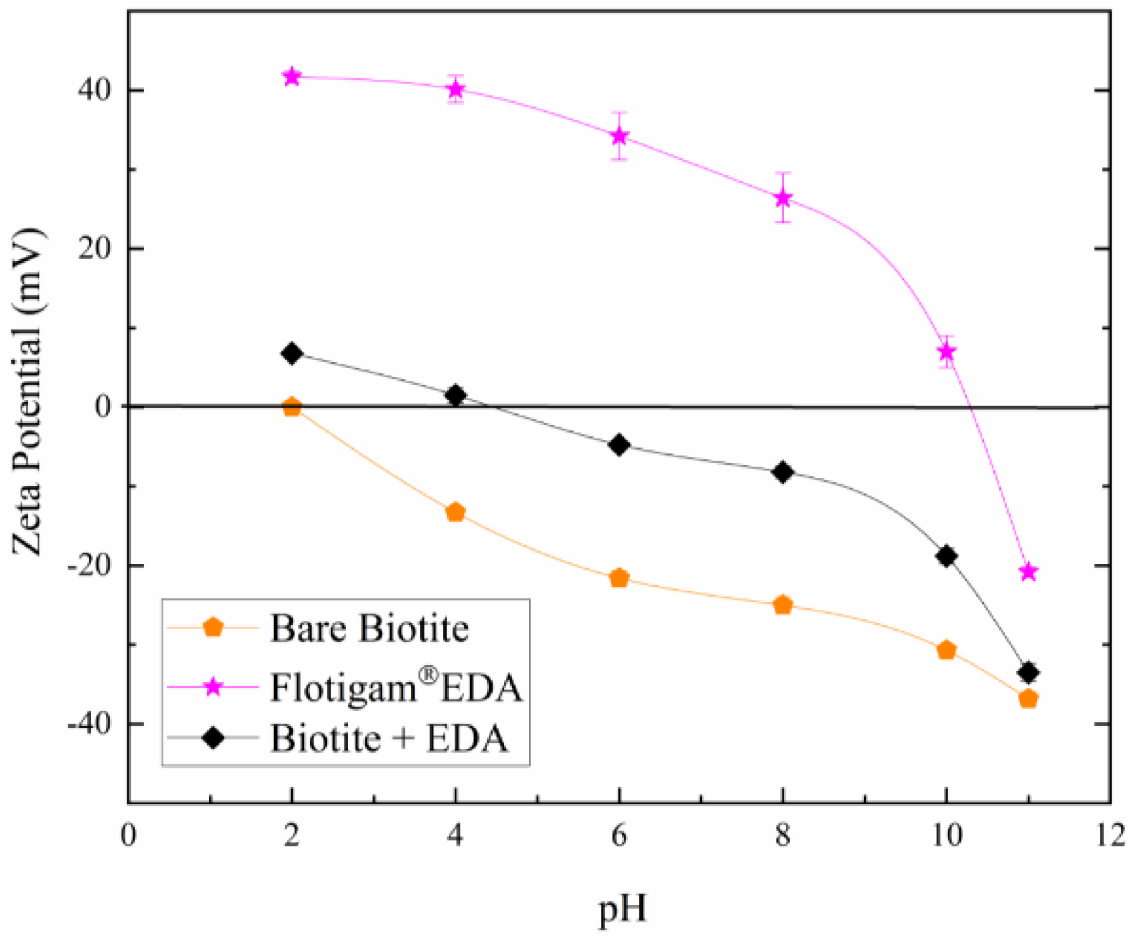

Figure 5. Zeta potentials of biotite as a function of $\mathrm{pH}$ in the absence and presence of $30 \mathrm{mg} / \mathrm{dm}^{3}$ Flotigam ${ }^{\circledR}$ EDA.

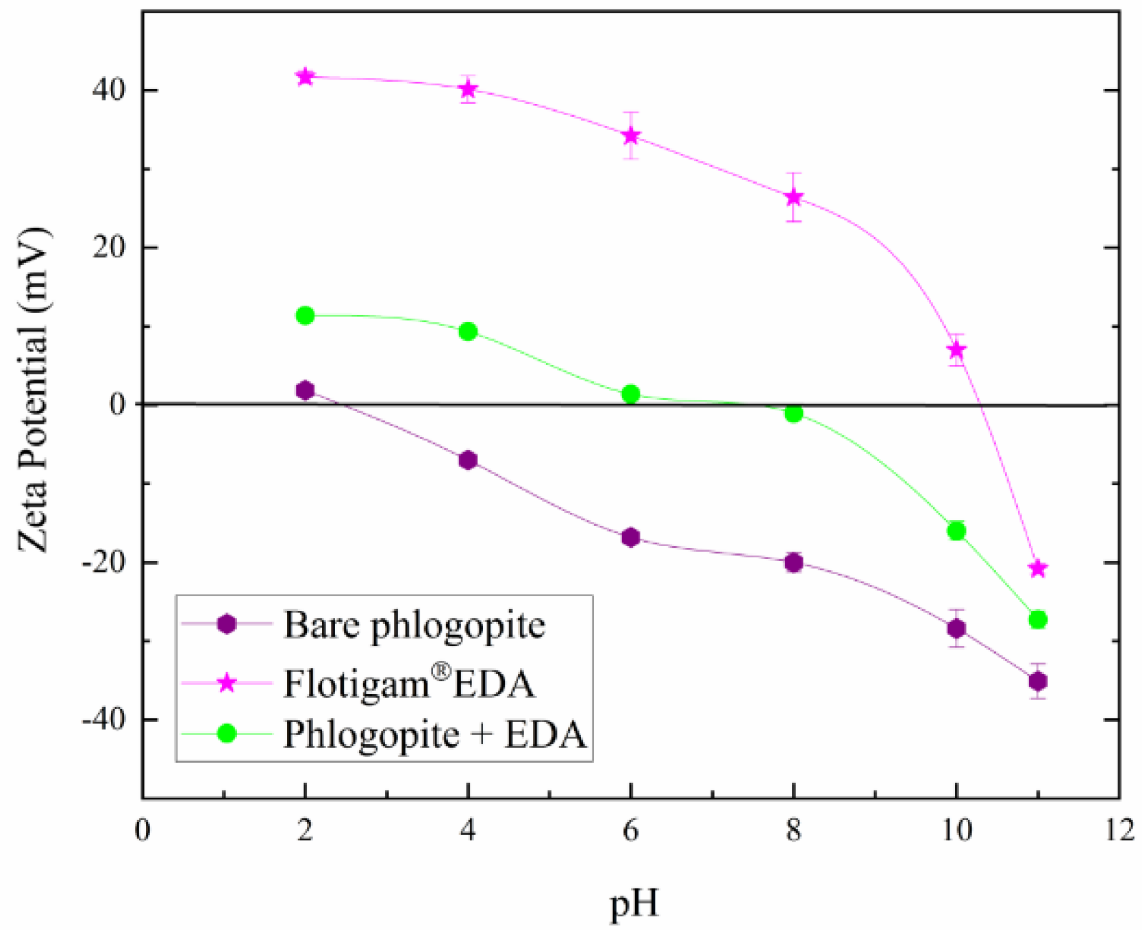

Figure 6. Zeta potentials of phlogopite as a function of $\mathrm{pH}$ in the absence and presence of $30 \mathrm{mg} / \mathrm{dm}^{3}$ Flotigam ${ }^{\circledR}$ EDA. 


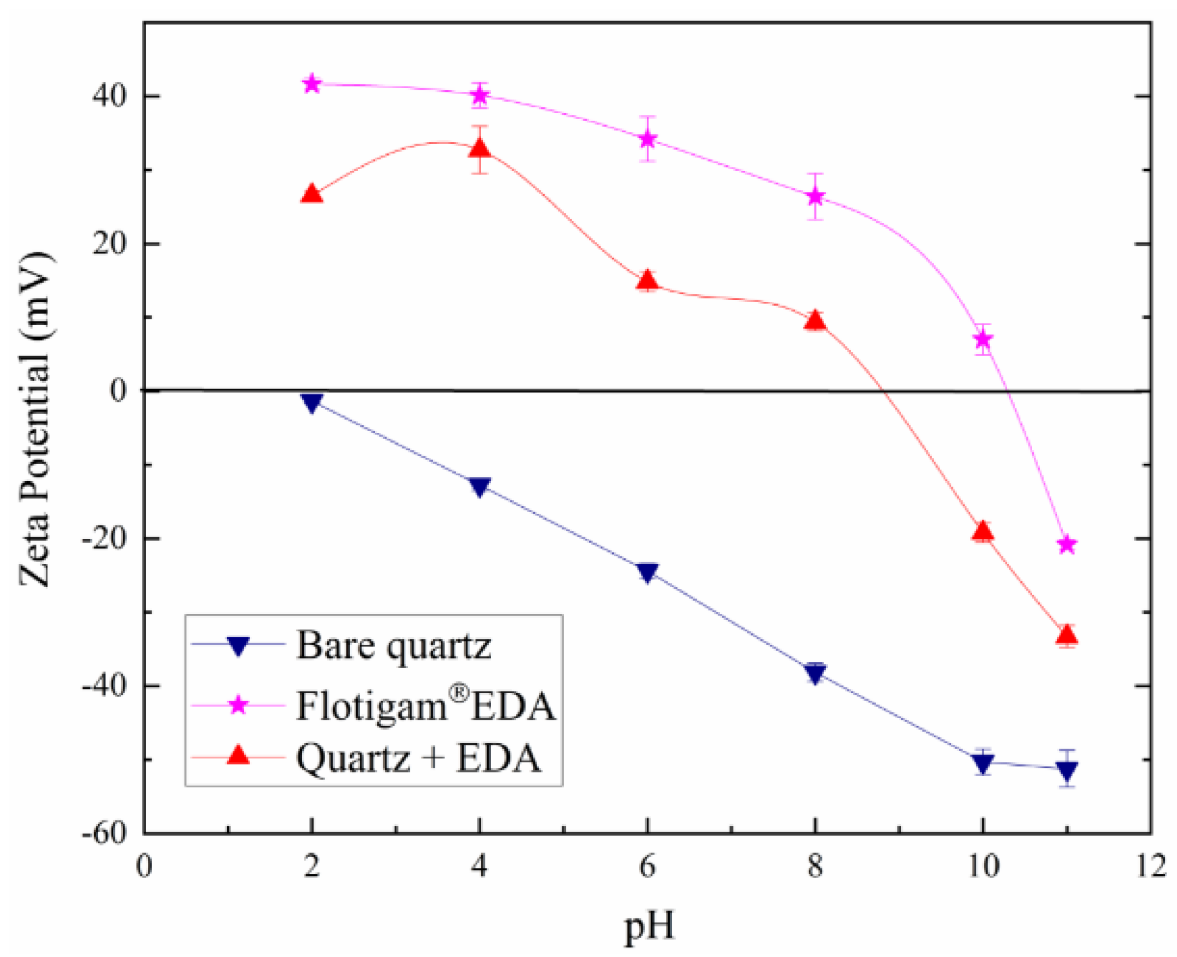

Figure 7. Zeta potentials of quartz as a function of $\mathrm{pH}$ in the absence and presence of $30 \mathrm{mg} / \mathrm{dm}^{3}$ Flotigam ${ }^{\circledR}$ EDA.

Table 2. IEPs of quartz, biotite, and phlogopite were reported in the literature.

\begin{tabular}{cc}
\hline Mineral & IEP \\
\hline Quartz & $1.9[10],<2[37], 2[44], 2.1[45], 2[46]$ \\
Biotite & $<1.5[13],<1[24], 2.6[47], 3[48]$ \\
Phlogopite & $<1.5[13], 2.1[48], 2.1[49], 2.4[50]$ \\
\hline
\end{tabular}

In general, zeta potential results showed that EDA adsorbed onto the surface of all the mineral samples. The zeta potential magnitudes of the EDA-treated quartz in a wide range of $\mathrm{pH}$ values are higher than phlogopite and biotite (Figure 7). Indeed, the quartz surface treated with EDA is more positive than the phlogopite and biotite. This can be explained by the fact that bare quartz surfaces had more negative surface energy than pure phlogopite and biotite. This could lead to a significant electrostatic attraction between quartz and the EDA cationic species. At $\mathrm{pH} 10$ and $30 \mathrm{mg} / \mathrm{dm}^{3} \mathrm{EDA}$, the surface charge of the conditioned quartz was significantly shifted toward positive charges compared to the treated biotite and phlogopite surfaces. This depicted that silicate minerals with a higher share of silanol groups on their surfaces (lower share of metallic ions on their surfaces) could be highly affected by cationic collectors, and their surface hydrophobicity would be markedly increased. This outcome is consistent with micro-flotation results, where higher floatability of quartz at $30 \mathrm{mg} / \mathrm{dm}^{3}$ was achieved than the micaceous minerals, indicating much higher surface saturation of quartz by EDA comparing micaceous minerals.

\subsubsection{EDA Concentration}

Zeta potential results in the presence of different EDA concentrations at $\mathrm{pH} 10$ demonstrated that the surface charge of all minerals became more positive by increasing the EDA concentration (Figure 8). However, the zeta potential of phlogopite and biotite was more positive over the investigated EDA concentration range, especially in concentrations more than $30 \mathrm{mg} / \mathrm{dm}^{3}$. The zeta potential variations for micaceous minerals were almost the same. In the $30 \mathrm{mg} / \mathrm{dm}^{3} \mathrm{EDA}$, the zeta potential of bare phlogopite and biotite shifted from $-28.4 \mathrm{mV}$ and $-30.7 \mathrm{mV}$ to $-16.1 \mathrm{mV}$ and $-18.8 \mathrm{mV}$, respectively. However, the quartz zeta 
potential became $-20.4 \mathrm{mV}$ from $-50.3 \mathrm{mV}$ (bare quartz). This is while, by increasing EDA concentration from 30 to $140 \mathrm{mg} / \mathrm{dm}^{3}$, the zeta potential of micaceous minerals was sharply shifted toward positive charges (Figure 8). This incremental trend was higher than quartz, indicating more desire for micaceous minerals to absorb EDA in higher concentrations. Indeed, increasing the EDA concentration caused saturation of the surface of micaceous minerals, and as a result, increased their floatability. In other words, increasing the mineral surface charges by adding EDA was a shred of evidence for its physical adsorption, which could lead to an increase in their floatability (Figure 1).

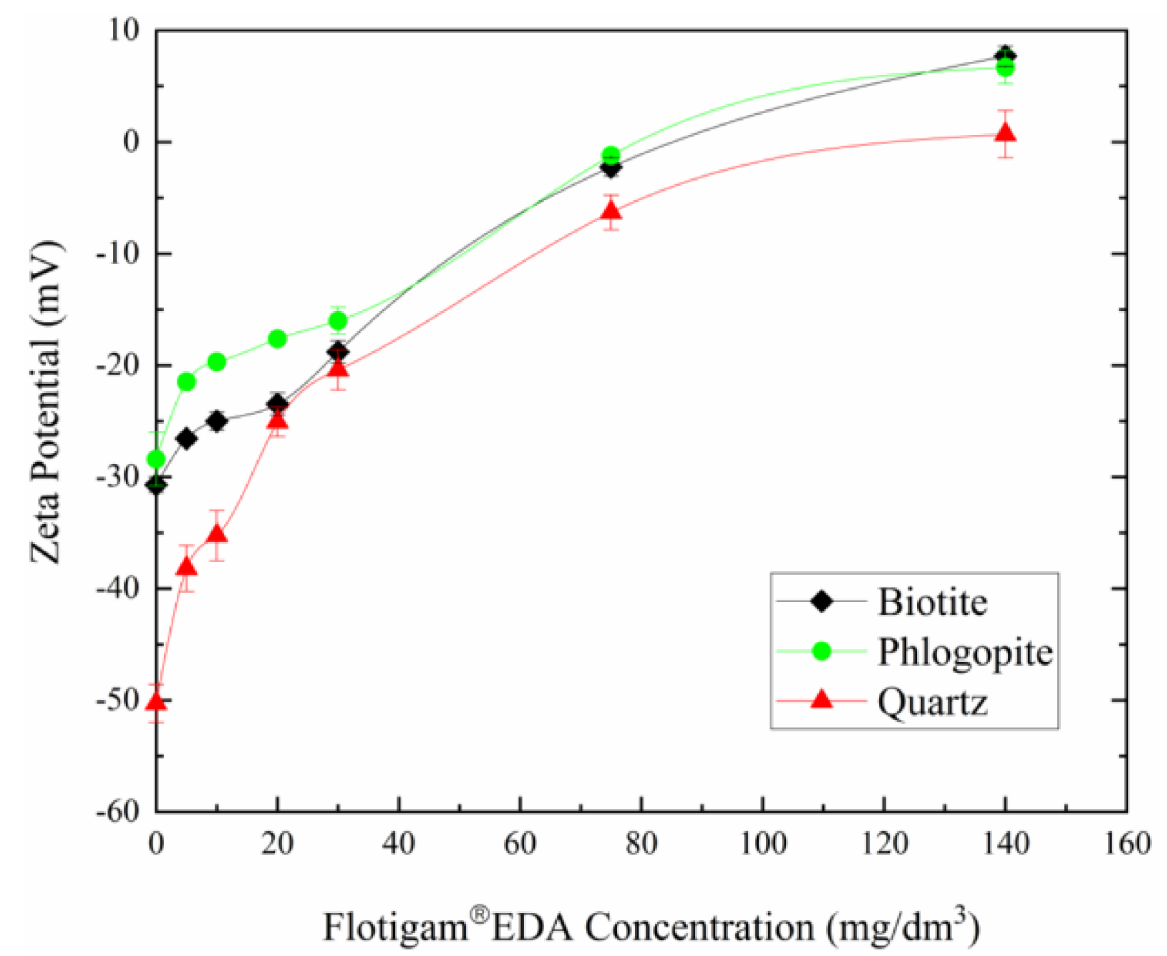

Figure 8. Zeta potentials of biotite, phlogopite, and quartz as a function of Flotigam ${ }^{\circledR}$ EDA concentration at $\mathrm{pH} 10$.

\section{Conclusions}

In order to understand the effect of Flotigam ${ }^{\circledR}$ EDA, ether monoamine collector, on the cationic flotation of biotite, phlogopite, and quartz, single mineral micro-flotation tests along with surface analyses were employed. Micro-flotation results indicated that in various EDA concentrations, the floatability of quartz was significantly higher than phlogopite and biotite. Biotite and phlogopite could satisfactorily float at a higher dosage of EDA, depicting more collector molecules needed to saturate the surface of these minerals than the quartz. Due to the contact angle measurements on an ideal surface of minerals, all minerals' obtained contact angle values were almost similar. Adsorption tests by measuring the residual surface tension of mineral suspensions indicated that phlogopite and biotite could adsorb EDA on their surfaces, much higher than quartz. Zeta potential measurements confirmed a higher affinity of micaceous minerals to EDA at higher concentrations, matching with micro-flotation and adsorption test results. Zeta potential outcomes also indicated the adsorption mechanism could be physical interaction between negative surface sites of these minerals and the positive EDA molecules.

Author Contributions: A.T.: Conceptualization, Methodology, Data curation Writing-original draft, Visualization, Investigation, Software, Validation, Writing-review \& editing. R.D.: Conceptualization, Visualization, Writing-original draft, Investigation, Funding acquisition, Supervision. H.M.-M.: Data curation, Writing-original draft, Supervision. L.d.S.L.F.: Conceptualization, Su- 
pervision, Project administration, Funding acquisition, Resources. S.C.C.: Conceptualization, Data curation, Writing — original draft, Supervision, Writing—review \& editing. All authors have read and agreed to the published version of the manuscript.

Funding: The first author would like to thank the Vale Institute of Technology (ITV) for providing financial support for this work.

Institutional Review Board Statement: Not applicable.

Informed Consent Statement: Not applicable.

Data Availability Statement: The study did not report any data.

Conflicts of Interest: The authors declare that there is no conflict of interest.

\section{References}

1. Leja, J. Surface Chemistry of Froth Flotation; Springer: Vancouver, BC, Canada, 1981. [CrossRef]

2. Wills, B.A.; Napier-Munn, T. Wills' Mineral Processing Technology; Elsevier BV: Cornwall, UK, 2005. [CrossRef]

3. Han, G.; Wen, S.; Wang, H.; Feng, Q. Surface Sulfidization Mechanism of Cuprite and Its Response to Xanthate Adsorption and Flotation Performance. Miner. Eng. 2021, 169, 106982. [CrossRef]

4. Zhang, Q.; Wen, S.; Feng, Q.; Liu, Y. Activation Mechanism of Lead Ions in the Flotation of Sulfidized Azurite with Xanthate As Collector. Miner. Eng. 2021, 163, 106809. [CrossRef]

5. Kohad, V.P. Flotation of Sulphide Ores-HZL Experience. Proceedings of Workshop on Froth Flotation: Recent Trends, Bhubaneswar, India, 22-24 September 1998.

6. Lynch, A.J.; Johnson, N.W.; McKee, D.J.; Thorne, G.C. The Behaviour of Minerals in Sulphide Flotation Processes, With Reference to Simulation and Control. J. Sou. Afr. Inst. Min. And. Metal. 1974, 74, 349-361.

7. Tohry, A.; Dehghani, A. Effect of Sodium Silicate on the Reverse Anionic Flotation of a siliceous-phosphorus Iron Ore. Sep. Purif. Technol. 2016, 164, 28-33. [CrossRef]

8. Tohry, A.; Dehghani, A.; Mojtahedzadeh, A. Investigation of Silica Removal from Hematite Concentrate of Chador-Malu Flotation Circuit. Ir. J. Min. Eng. 2015, 10, 1-10.

9. Tohry, A.; Dehghan, R.; Hatefi, P.; Chelgani, S.C. A Comparative Study Between the Adsorption Mechanisms of Sodium Co-Silicate and Conventional Depressants for the Reverse Anionic Hematite Flotation. Sep. Sci. Technol. 2021, 1-18. [CrossRef]

10. Tohry, A.; Dehghan, R.; Filho, L.D.S.L.; Chelgani, S.C. Tannin: An Eco-Friendly Depressant for the Green Flotation Separation of Hematite from Quartz. Miner. Eng. 2021, 168, 106917. [CrossRef]

11. Tohry, A.; Dehghan, R.; Chelgani, S.C.; Rosenkranz, J.; Rahmani, O.A. Selective Separation of Hematite by a Synthesized Depressant in Various Scales of Anionic Reverse Flotation. Miner. 2019, 9, 124. [CrossRef]

12. Tohry, A.; Dehghan, R.; Zarei, M.; Chelgani, S.C. Mechanism of Humic Acid Adsorption As a Flotation Separation Depressant on the Complex Silicates and Hematite. Miner. Eng. 2021, 162, 106736. [CrossRef]

13. Leal Filho, L.S.; Assist, S.M.; Barros, L.A.F.; Peres, A.E.C. Activation and Adepression of Silicates During Anionic Flotation of Igneous Apatite. In Benefication of Phosphate (Fundamentals and Technology); Society for Mining, Metallurgy and Exploration Inc. (SME): Littleton, CO, USA, 2002.

14. Derhy, M.; Taha, Y.; Hakkou, R.; Benzaazoua, M. Review of the Main Factors Affecting the Flotation of Phosphate Ores. Minerals 2020, 10, 1109. [CrossRef]

15. Arol, A.; Aydogan, A. Recovery Enhancement of Magnetite Fines in Magnetic Separation. Colloids Surfaces A Physicochem. Eng. Asp. 2004, 232, 151-154. [CrossRef]

16. Filippov, L.; Severov, V.; Filippova, I. An Overview of the Beneficiation of Iron Ores via Reverse Cationic Flotation. Int. J. Miner. Process. 2014, 127, 62-69. [CrossRef]

17. Filippov, L.; Filippova, I.; Severov, V. The Use of Collectors Mixture in the Reverse Cationic Flotation of Magnetite Ore: The Role of Fe-Bearing Silicates. Miner. Eng. 2010, 23, 91-98. [CrossRef]

18. Tohry, A.; Dehghani, A.; Hosseini-Nasab, M. Removal of Fine Gangue Minerals from Chador-Malu Iron Concentrate Using Hydroseparator. Physicochem. Prob. Mine. Proc 2017, 53, 250-263. [CrossRef]

19. Manser, R.M. Handbook of Silicate Flotation; Warren Spring Laboratory: Stevenage, UK, 1975.

20. Araujo, A.; Viana, P.; Peres, A. Reagents in Iron Ores Flotation. Miner. Eng. 2005, 18, 219-224. [CrossRef]

21. Severov, V.; Filippov, L.; Filippova, I. Relationship Between Cation Distribution With Electrochemical and Flotation Properties of Calcic Amphiboles. Int. J. Miner. Process. 2016, 147, 18-27. [CrossRef]

22. Hu, Y.; Liu, X.; Xu, Z. Role of Crystal Structure in Flotation Separation of Diaspore from Kaolinite, Pyrophyllite and Illite. Miner. Eng. 2003, 16, 219-227. [CrossRef]

23. Rao, K.H.; Antti, B.-M.; Forssberg, K.S.E. Flotation of Mica Minerals and Selectivity Between Muscovite and Biotite While Using Mixed anionic/Cationic Collectors. Mining Met. Explor. 1990, 7, 127-132. [CrossRef]

24. Filippov, L.; Duverger, A.; Filippova, I.V.; Kasaini, H.; Thiry, J. Selective Flotation of Silicates and Ca-Bearing Minerals: The Role of Non-Ionic Reagent on Cationic Flotation. Miner. Eng. 2012, 36-38, 314-323. [CrossRef] 
25. Rao, K.H.; Cases, J.M.; Barres, O.; Forssberg, K.S.E. Flotation, Electrokinetic and FT-IR Studies of Mixed anionic/Cationic Col-Lectors in muscovite-biotite System. In Mineral Processing: Recent Advances and Future Trends.; Mehrotra, S.P., Shekhar, R., Eds.; Allied Publishing Ltd.: New Dehli, India, 1995; pp. 29-44.

26. Rao, K.H.; Forssberg, K. Mixed Collector Systems in Flotation. Int. J. Miner. Process. 1997, 51, 67-79. [CrossRef]

27. Teng, Q.; Wen, Q.; Yang, Z.; Liu, S. Evaluation of the Biological Flotation Reagent Obtained from Paenibacillus Amylolyticus in Magnetite and Phlogopite Flotation System. Colloids Surfaces A: Physicochem. Eng. Asp. 2021, 610, 125930. [CrossRef]

28. Ma, M. Froth Flotation of Iron Ores. Int. J. Min. Eng. Miner. Process. 2012, 1, 56-61. [CrossRef]

29. Gaudin, A.M.; Morrow, J.G. Adsorption of Dodecylamine on Hematite and Its Flotation Effect. Trans. Metall. Soc. AIME 1954, 12, 1196-1202.

30. Papini, R.M.; Brandão, P.R.G.; Peres, A. Cationic Flotation of Iron Ores: Amine Characterization and Performance. Mining Met. Explor. 2001, 18, 5-9. [CrossRef]

31. Fuerstenau, D.W. Streaming Potential Studies on Quartz in Solutions of Aminium Acetates in Relation to the Formation of HemiMicelles at the Quartz-Solution Interface. J. Phys. Chem. 1956, 60, 981-985. [CrossRef]

32. Pattanaik, A.; Venugopal, R. Investigation of Adsorption Mechanism of Reagents (Surfactants) System and Its Applicability in Iron Ore Flotation - An Overview. Colloid Interface Sci. Commun. 2018, 25, 41-65. [CrossRef]

33. Somasundaran, P.; Lou, A. Iron Oxide Mineral Flotation Fundamentals; Parekh, B.K., Miller, J.D., Eds.; Advances in Flotation Technology, SME: New York, NY, USA, 1999; pp. 23-43.

34. Cassola, M.S.; Silva, W.C.; Bartalini, N.M. Development and Applications on Collectors at the Iron Ore Flotation, Technical Report; Application \& Development Laboratory of Clariant Co.: Sao Paulo, Brazil, 2015.

35. Calgaroto, S.; Azevedo, A.; Rubio, J. Separation of Amine-Insoluble Species by Flotation With Nano and Microbubbles. Miner. Eng. 2016, 89, 24-29. [CrossRef]

36. Ren, L.; Qiu, H.; Zhang, Y.; Nguyen, A.V.; Zhang, M.; Wei, P.; Long, Q. Effects of Alkyl Ether Amine and Calcium Ions on Fine Quartz Flotation and Its Guidance for Upgrading Vanadium from Stone Coal. Powder Technol. 2018, 338, 180-189. [CrossRef]

37. Lelis, D.F.; Da Cruz, D.G.; Lima, R.M.F. Effects of Calcium and Chloride Ions in Iron Ore Reverse Cationic Flotation: Fundamental Studies. Miner. Process. Extr. Met. Rev. 2019, 40, 402-409. [CrossRef]

38. Tohry, A.; Dehghan, R.; Oliveira, A.V.; Chelgani, S.C.; Filho, L.D.S.L. Enhanced Washburn Method (EWM): A Comparative Study for the Contact Angle Measurement of Powders. Adv. Powder Technol. 2020, 31, 4665-4671. [CrossRef]

39. KRÜSS GmbH. Processor Tensiometer K12: User's Manual; KRÜSS GmbH: Hamburg, Germany, $1994 ;$ p. 84.

40. Jiang, J.; Shang, X.; Wang, H.; Xu, Y.-B.; Gao, Y.; Zhou, Q. Diagnostic value of contrast-enhanced ultrasound in thyroid nodules with calcification. Kaohsiung J. Med. Sci. 2015, 31, 138-144. [CrossRef]

41. Bailey, S.W. CLASSIFICATION and STRUCTURES of the MICAS. Micas 1984, 13, 1-12. [CrossRef]

42. Kramer, A.; Gaulocher, S.; Martins, M.; Filho, L.D.S.L. Surface Tension Measurement for Optimization of Flotation Control. Procedia Eng. 2012, 46, 111-118. [CrossRef]

43. de Matos, V.E.; Nogueira, S.D.C.S.; Kowalczuk, P.B.; da Silva, G.R.; Peres, A.E.C. Differences in Etheramines Froth Properties and the Effects on Iron Ore Flotation. Part I: Two-Phase Systems. Miner. Process. Extr. Met. Rev. 2021, 1-8. [CrossRef]

44. Ruan, Y.; Zhang, Z.; Luo, H.; Xiao, C.; Zhou, F.; Chi, R. Effects of Metal Ions on the Flotation of Apatite, Dolomite and Quartz. Minerals 2018, 8, 141. [CrossRef]

45. Abaka-Wood, G.B.; Addai-Mensah, J.; Skinner, W. A Study of Flotation Characteristics of Monazite, Hematite, and Quartz Using Anionic Collectors. Int. J. Miner. Process. 2017, 158, 55-62. [CrossRef]

46. Fan, G.; Wang, L.; Cao, Y.; Li, C. Collecting Agent-Mineral Interactions in the Reverse Flotation of Iron Ore: A Brief Review. Minerals 2020, 10, 681. [CrossRef]

47. Rath, R.; Subramanian, S. Studies on Adsorption of Guar Gum onto Biotite Mica. Miner. Eng. 1997, 10, 1405-1420. [CrossRef]

48. De Carvalho, J.A.E.; Brandão, P.R.G.; Henriques, A.B.; De Oliveira, P.S.; Cançado, R.Z.L.; Da Silva, G.R. Selective Flotation of Apatite from Micaceous Minerals Using Patauá Palm Tree Oil Collector. Miner. Eng. 2020, 156, 106474. [CrossRef]

49. Wang, Q.; Heiskanen, K. Dispersion Selectivity and Heterocoagulation in Apatite-Hematite-Phlogopite Fine Particle Suspensions II. Dispersion Selectivities of the Mineral Mixtures. Int. J. Miner. Process. 1992, 35, 133-145. [CrossRef]

50. Bai, Y.; Li, C.; Song, W.; An, H.; Zhao, J. Application of Sodium Dodecyl Glycinate to the Flotation of Deslimed Molybdenum Tailings. Physicochem. Prob. Miner. Proc. 2019, 55, 1120-1131. [CrossRef]

51. Churaev, N.; Sergeeva, I.; Sobolev, V.; Jacobasch, H.-J.; Weidenhammer, P.; Schmitt, F.-J. Modification of Quartz Surfaces Using Cationic Surfactant Solutions. Colloids Surfaces A: Physicochem. Eng. Asp. 2000, 164, 121-129. [CrossRef]

52. Smith, R.W.; Scott, J.L. Mechanisms of Dodecylamine Flotation of Quartz. Miner. Process. Extr. Met. Rev. 1990, 7, 81-94. [CrossRef]

53. Kosmulski, M. Chemical Properties of Material Surfaces; Marcel Dekker: New York, NY, USA, 2001. 